\section{O LUGAR DO PSICANALISTA NOS HOSPITAIS GERAIS: ENTRE OS DISPOSITIVOS CLIINICOS E OS INSTITUCIONAIS ${ }^{1}$}

\author{
The Psychoanalyst Place in General Hospitals: The Clinical \\ and the Institutional Dimensions
}

\author{
El Lugar del Analista en Hospitales Generales: Entre \\ Dispositivos Médicos y Institucional
}

\section{La Place de L'analyste dans les Hôpitaux Généraux: Entre Dispositifs Médicaux et Institutionnelle}

\begin{abstract}
Resumo
O principal objetivo deste artigo é apresentar qual o lugar (função) do psicanalista nos hospitais gerais. Investiga-se esse lugar a partir de duas dimensões, que devem ser articuladas: a dimensão da clínica psicanalítica e a dimensão da instituição. Conclui-se que o lugar do psicanalista nos hospitais se encontra entre essas duas dimensões.
\end{abstract}

Palavras-chave: psicanálise; medicina; hospital geral; psicanalista; função.

\begin{abstract}
The main objective of this paper is to present what place (function) of the psychoanalyst in general hospitals. Investigates this place from two dimensions that should be articulated: the dimension of psychoanalytic practice and the size of the institution. . It was concluded that the place of the psychoanalysts in general hospitals is somewhere between the clinical dimension and the institutional dimension.
\end{abstract}

Keywords: psychoanalysis; medicine; general hospital; psychoanalyst; function.

\section{Resumen}

El objetivo deste trabajo es presentar qué lugar (función) del psicoanalista en los hospitales generales. Investiga este lugar desde dos dimensiones, que deben ser articulados: el tamaño de la clínica psicoanalítica y el tamaño de la institución. Llegamos a la conclusión de que el lugar del analista en los hospitales es entre estas dos dimensiones.

Palabras clave: psicoanálisis; medicina; hospital general; psicoanalista; función.

\section{Résumé}

Le but de cet article est de présenter ce lieu (fonction) du psychanalyste dans les hôpitaux généraux. Enquêter sur ce lieu de deux dimensions, qui doivent être articulés: la taille de la clinique psychanalytique et la taille de l'institution. Nous concluons que le lieu de l'analyste dans les hopitaux est entre ces deux dimensions.

Mots-clés: psychanalyse; medicine; hôpital général; psychanalyste; fonction.
Artigo Original
1) Especialista em Teoria Psicanalítica (UFMG); Mestre em Psicologia Clínica e Cultura (UnB).

2) Psicanalista. Professora Adjunta do Departamento de Psicologia Clínica do Instituto de Psicologia e do Programa de Psicologia Clínica e Cultura (UnB); Doutora em Filosofia (Universidade de Paris VIII).

1 Este artigo é um desdobramento da dissertação de mestrado de Maíla Do Val Machado. A dissertação foi apresentada ao Programa de Pós-Graduação em Psicologia Clínica e Cultura do Instituto de Psicologia da Universidade de Brasília.

Recebido em: 30/06/2012 Revisado em: 05/09/2013 Aceito em: 28/05/2014 
As questões apresentadas neste estudo surgiram a partir de alguns trabalhos desenvolvidos em hospitais gerais particulares, localizados na cidade de Belo Horizonte. Ao longo do artigo, quando mencionamos as instituições hospitalares, estamos nos referindo a esses hospitais com suas devidas especificidades: geral e particular. Em todos eles há um Serviço de Psicologia composto por psicólogos e estagiários de psicologia. $\mathrm{O}$ trabalho dessas equipes voltase, sobretudo, para os atendimentos a pacientes e familiares.

Este estudo é uma pesquisa teórica que abrange a clínica, e nele será usado material recolhido no cotidiano da práxis nos hospitais gerais para fins de investigação. As principais referências teóricas são as concepções da obra de Sigmund Freud e do ensino de Jacques Lacan. Recorre-se também a alguns autores renomados na área - psicanálise e hospital - que apresentam ideias importantes para o desenvolvimento do nosso estudo.

A inserção da psicanálise nos hospitais gerais do Brasil teve um crescimento a partir da última década do século XX. Atualmente, observa-se, cada vez mais, a presença do psicanalista nesses espaços e um aumento da demanda por suas intervenções. Com isso, nota-se maior interesse pelo tema nos congressos, além do aumento da quantidade de publicações sobre o assunto. Apesar da ampliação do número de publicações, ainda há necessidade de novas discussões sobre o tema, principalmente porque é uma clínica relativamente recente e que se encontra em construção.

A extensão da psicanálise para além dos consultórios particulares exige do analista formalizar teoricamente a prática a partir dos próprios fundamentos do campo psicanalítico. É essencial que o analista reflita, repense e reconstrua condições para a formalização da sua prática, considerando as especificidades da sua clínica. Nesse percurso, o analista se depara com vários impasses e desafios, principalmente porque nos hospitais predominam o discurso e a ética da medicina, que se distinguem radicalmente dos referenciais psicanalíticos. Nessas instituições, prevalece a busca da padronização de comportamentos e de crenças voltadas para a normatização de atitudes diante dos pretensos padrões de normalidade. É um contexto onde a subjetividade é tomada como risco e como empecilho para o sucesso do tratamento médico. Todavia, numa perspectiva contrária àquela que predomina no hospital, a psicanálise vem mostrar que não há projeto científico nem dor capaz de anular a subjetividade humana. Ao ter como referência a experiência subjetiva na clínica, o psicanalista trabalha o particular de cada caso na instituição não no viés de adaptar os indivíduos à situação de adoecimento, mas no sentido de propiciar, a partir desta, o resgate do sujeito em sua singularidade radical.

É importante destacar que os desafios e impasses com que o analista se depara nos hospitais têm uma função essencial - indicar a direção para a formalização da prática. Por isso, ao longo deste artigo, recorremos a várias situações que colocam o psicanalista diante de impasses e desafios, bem como a experiências da prática do analista nesses espaços.

A extensão da clínica psicanalítica para os hospitais nos possibilita debater questões que colocam a práxis do psicanalista diante de desafios clínicos, teóricos e institucionais. Dessa forma, este estudo visa investigar, por meio de uma articulação entre a teoria, a prática e a pesquisa, qual o lugar do psicanalista nos hospitais gerais. Esse lugar - que não se refere a um espaço geográfico, mas a um lugar enquanto função - será abordado a partir de duas vertentes: a dimensão da clínica e a dimensão da instituição hospitalar. Ressalta-se aqui que não se trata de transpor uma prática clínica exercida no âmbito do consultório privado para as instituições hospitalares, mas, sobretudo, de localizar as especificidades da clínica psicanalítica nos hospitais gerais. Neles, o analista não propõe uma experiência analítica propriamente dita, mas ao se inserir numa instituição, ele pode criar um espaço de escuta que autorize as manifestações da subjetividade que o médico se propõe a tratar.

\section{O Lugar do Psicanalista nos Hospitais Gerais: Dimensão Clínica}

A difusão da clínica psicanalítica para além dos consultórios particulares teve como consequência a implicação da psicanálise nos hospitais gerais. No entanto, essa abertura para a prática psicanalítica no contexto hospitalar não legitima o lugar do analista nesses espaços. Assim, surgem as perguntas: $O$ que sustenta o lugar do psicanalista no hospital? Que lugar é esse? Essas questões serão discutidas a partir de duas vertentes: a do discurso e a da ética. Escolhemos essas vias justamente porque elas convocam o analista a ocupar um lugar particular no hospital, o que gera alguns impasses e desafios.

\section{Discurso Médico X Discurso do Psicanalista}

O hospital é um espaço de entrecruzamentos de discursos. Entre eles temos o discurso do analista e o discurso do médico que, conforme veremos ao longo deste tópico, se diferenciam de forma radical. O discurso do médico prevalece na instituição hospitalar e é a referência dos outros profissionais que atuam nesse local, com exceção do psicanalista. A psicanálise é uma prática que se realiza sob a forma de um discurso que lhe é próprio e, por isso, sustentá-lo é algo essencial para sua eficácia. Desse modo, para o analista é um grande desafio sustentar seu discurso num local marcado pelos critérios da medicina. 
Neste tópico serão apresentadas algumas distinções entre o discurso do médico e o discurso do analista. É de grande interesse para este artigo discutir as diferenças entre esses discursos, pois delas provêm as dificuldades encontradas pela psicanálise para se fazer efetiva na instituição hospitalar. Para desenvolver a discussão aqui proposta, recorremos à teoria do discurso, tal como postulada por Lacan (1969-1970/1992) no seu Seminário $O$ avesso da psicanálise. $O$ objetivo aqui não é expor toda a complexidade da conceitualização dos quatro discursos, mas apenas retomar aquilo que for necessário para o tema em questão. Dentre os quatro discursos, maior ênfase será dada ao discurso do mestre e ao discurso do analista.

A partir da formulação de Lacan (1969-1970/1992) sobre a teoria dos discursos, o psicanalista passa a ter um importante referencial com consistência teórica, possibilitando examinar e dialetizar sua função nos diversos campos da cultura. Ao considerar a psicanálise como um discurso, o analista tornase efeito desse discurso, que precisa ser sustentado onde quer que ele atue.

A noção de discurso em Lacan (1969-1970/1992) procurou determinar o que é mais necessário à estrutura do discurso do que a palavra, o que excede a palavra permitindo a inscrição dos atos e conduta do sujeito falante no campo dos enunciados, de modo a se extrair sua relação fundamental. Por isso ele afirma que prefere "é um discurso sem palavras" (Lacan, 1969-1970/1992, p.11), já que o discurso pode subsistir nessas relações fundamentais. Isso significa que no momento em que o sujeito está inserido num discurso, seus atos e condutas demonstram "dizeres" essenciais sem que as palavras sejam necessárias. Nesse sentido, a ideia de um discurso sem palavras remete à insuficiência da linguagem, apontando para um campo que ultrapassa as palavras. Tratase aí da dimensão do gozo e do real articulado à noção de discurso.

Souza (2008), ao tratar sobre os discursos na psicanálise a partir das concepções lacanianas, diz que num primeiro momento do ensino de Lacan, o discurso se manteve relacionado à fala. Nesse período, a psicanálise se voltava, sobretudo, para uma topologia do significante que fundamentava a própria noção de estrutura simbólica e da linguagem.

A partir do Seminário XVII, O avesso da psicanálise, Lacan (1969-1970/1992) propõe uma modificação estrutural em relação ao que até o momento havia proposto. Desenvolveu a noção de semblante - uma condição que coloca o objeto numa zona limite entre o simbólico e o real - que, em última análise, desloca a função da fala, para atribuir uma importância à letra e à escritura, que passam a ter consequências na renúncia ao gozo que o discurso institui.

Nessa ocasião, Lacan procurou estabelecer uma diferença entre significante e letra, considerando esta como um elemento que viria possibilitar uma via de acesso direto ao real. Apesar da impossibilidade de falar do real, Lacan afirma que deveria escrevê-lo. Escrever os discursos sob a forma algébrica, dos matemas, é uma maneira que ele encontrou de transmitir o real da estrutura, que é o próprio real do gozo e o real do sujeito. Isso significa que não há a totalidade que sustenta um discurso, ou seja, as palavras não podem dizer tudo. Há sempre uma perda, uma renúncia ao gozo, a presença do real. Assim, ao tratar de um discurso sem palavras, Lacan aponta tanto para a insuficiência da linguagem quanto para a dimensão do real que aí se encontra.

No Seminário XVII, Lacan (1969-1970/1992) tenta abordar, através dos discursos, os laços sociais possíveis apesar do real impossível. O discurso é uma tentativa de estabelecer um laço social com o outro que decorre de uma perda de gozo. Essa perda implica na própria entrada no discurso. Lacan sugere a existência de quatro discursos que regulam o laço social: o do mestre, o da histérica, o do psicanalista e o do universitário. Afirma que todo discurso compreende quatro elementos, que são seus matemas fundamentais: S1, o significante mestre; S2, o saber; a, mais-de-gozar; e \$, sujeito barrado pelo significante. Esses elementos obedecem a uma sequência ordenada que não pode ser desarrumada. Ao seguir essa ordem, eles podem mudar de lugar - quatro giros - adquirindo uma nova função no discurso. É a partir dessas rotações que se obtêm os quatro diferentes discursos.

$\mathrm{Na}$ ordenação dos quatro matemas que escrevem os discursos, há uma estrutura algébrica:

Abaixo de cada letra situada na parte de cima, há uma barra de divisão que significa a operação do recalque. Os

$$
\text { Discurso do senhor }
$$

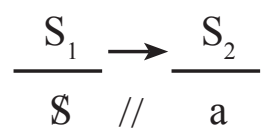

Discurso da univercidade

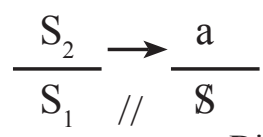

Discurso da histeria

Discurso do analista
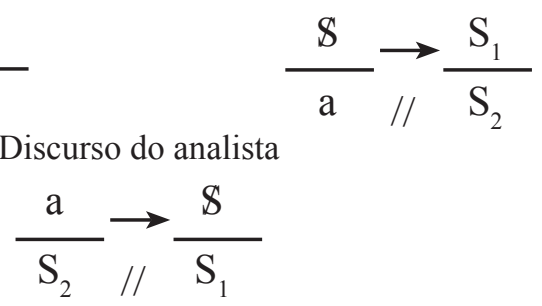

discursos se referem à relação do sujeito com o outro, porém o que a barra nos indica é que esta não é uma relação de consciência, mas que aí se insere a dimensão do inconsciente. Portanto, o sujeito em jogo é o sujeito do inconsciente.

A diferença entre cada um dos discursos se define pelo elemento que toma o primeiro lugar, na parte de cima, à esquerda, o agente - designado não como aquele que faz, mas aquele a quem se faz agir-, pois os outros três elementos 
(o outro, a produção e a verdade) se organizarão em torno dele. Os discursos são estruturados em torno da relação do agente e de seu outro, revelando a verdade a partir da qual cada agente se autoriza a agir e inscrevendo o que é esperado que o comandado, o outro, produza.

Os lugares no discurso guardam suas funções específicas e estabelecem os efeitos que cada um produz no sujeito. Ressalta-se que esses lugares ocupam uma posição fixa no discurso. Apenas os elementos (S1, S2, \$, a) fazem a rotação, obedecendo à sequência ordenada. Para qualquer um dos discursos, cada elemento adquire uma função, dependendo do lugar que ocupe em cada discurso.

A primeira conceituação dos lugares ocorre no Seminário XVII (Lacan, 1969-1970/1992). Mais tarde, Lacan renomeia esses lugares como sendo o de um semblante que, sustentado numa verdade, se dirige ao gozo que, assim agenciado, deixa cair um mais-de-gozar.

No discurso do mestre, a posição do agente, tal como aparece na primeira teorização dos lugares, é preenchida por $\mathrm{S} 1$, o significante mestre. A articulação $\mathrm{S} 1 \rightarrow \mathrm{S} 2$ refere-se à própria estrutura da linguagem, o que faz Lacan mencionar que o discurso do inconsciente corresponde a algo relativo à instituição do discurso do mestre.

Lacan (1969-1970/1992) aborda o discurso do mestre a partir da dialética do senhor e do escravo, de Hegel. De acordo com as concepções lacanianas, esse discurso situa-se no registro da dominação, da mestria, do poder. O significante mestre, a função significante sobre a qual se apoia a essência do senhor, institui um "outro lugar" - acima e à direita -, representado pelo $\mathrm{S} 2$, o saber. O outro adquire a função de um escravo ao qual é imposta uma injunção ao trabalho.

O S1 determina que o escravo trabalhe, visando produzir um saber, o S2, que toma a posição do outro. Lacan (19691970/1992) afirma que o campo do escravo é o do saber. Já o senhor não deseja saber absolutamente nada. $\mathrm{O}$ que the interessa é que a coisa funcione, que as coisas andem, que caminhem. Não lhe interessa saber por que funcionam. Ao mestre não interessa o saber, pois o obtém do escravo. É esse último que sabe sobre o funcionamento das coisas e cabe a ele transferir ao senhor o saber sobre o gozo. Ressalta-se que esse saber adquirido pelo escravo não é o "saber inconsciente", mas um tipo de "saber-fazer", que ele adquire com seu trabalho. Um saber, colocado acima e à direita, equivalente a um conhecimento que se pode imaginariamente esgotar pelo trabalho e pode ser acumulado e transmitido do escravo ao senhor.

No discurso do mestre, o gozo vem desse "outro lugar", campo do escravo, já que é ele quem tem o saber sobre o gozo. Por isso, Lacan também denominou o lugar acima e à direita como "lugar do gozo". No escravo, por mais que trabalhe, existirá sempre uma impotência para que seu saber possa ser todo apreendido pelo senhor. É um saber que se adquire com limites.

A intervenção de S1 sobre S2 implica na queda de um resto, uma perda de gozo, renúncia pulsional, que vem tomar o estatuto de objeto a. Essa intervenção determina não só uma perda, mas, sobretudo, uma produção que decorre desse trabalho que o escravo é forçado a fazer, pela injunção que o $\mathrm{S} 1$ lhe causa. O que se realiza sob esse estatuto de produção passou a ser designado como mais-de-gozar, aquilo que se relaciona com a repetição porque o sujeito resiste em perdêlo.

O que é produzido como efeito do discurso ocupa o lugar abaixo e à direita. Essa produção, que adquire o estatuto de objeto $a$, se realiza como algo que é oferecido ao senhor. Ao se referir a essa produção Lacan diz: "É isto, em suma, não mais do que isto, que o senhor tinha que fazer o escravo pagar, como único possuidor dos meios do gozo" (Lacan, 1969-1970/1992, p.75). Entretanto, o senhor não se beneficia daquilo que o escravo the oferece como produto do seu trabalho e esforço. Isso porque a produção, que é o objeto mais-de-gozar, não tem relação com a verdade do senhor.

No discurso do mestre, o lugar da verdade, embaixo e à esquerda, é ocupado pelo $\$$. O S1, traço que representa o sujeito para outro significante, intervém numa bateria de significantes, o S2, que integra um saber. Isso significa que S1 vem representar uma marca, um traço específico, por sua intervenção num campo já estruturado de um saber. Na medida em que S1 opera num âmbito em que outros significantes estão articulados entre si, surge o \$, que Lacan chamou de sujeito como dividido.

O sujeito ocupa o lugar da verdade, porém, por situarse abaixo da barra de recalque, permanece velado. Mesmo que o significante mestre represente o sujeito, ele o faz deixando-o mortificado, petrificado no próprio ato de sua constituição. Dessa forma, o discurso do mestre mascara a divisão do sujeito e oculta a castração do senhor. Isso implica que o senhor não pode apreender o que constitui sua própria verdade, mas espera encontrá-la a partir do trabalho do escravo. Essa ficção é fadada ao fracasso já que a produção não tem nenhuma relação com a verdade.

No discurso do mestre, o sujeito fica excluído de seu desejo. Observa-se essa ideia a partir de duas leituras do matema. O sujeito, ao localizar-se abaixo da barra do recalque, revela o recalcamento do desejo. Além disso, nesse discurso, existe uma impossibilidade discursiva de se escrever o artefato que sustenta o desejo e que se identifica como fantasma fundamental, $\$ \rightarrow$ a. Essa fórmula tem seu interesse por mostrar que o discurso do mestre é o único a tornar impossível essa relação.

Outra conexão presente no discurso do mestre é $\$ \rightarrow$ S2, que revela a possibilidade de que o saber se realize como um 
meio de gozo. O sujeito é lançado numa constante busca pelo saber. Entretanto, algo escapa a toda tentativa de alcançar um saber pleno e completo. A conexão $\$ \rightarrow$ S2 demonstra que apesar do fracasso, ainda há algo a se recuperar. O sujeito tenta reviver a primeira experiência de gozo, o gozo pleno, que deixa uma marca quando se inscreve no aparelho psíquico. A impossibilidade de reproduzir essa primeira vez conduz ao circuito da repetição, promovendo um outro gozo.

Os discursos guardam em sua combinatória de letras fixas (S1, S2, \$ e a) um impossível, um resto, que escapa a toda captura discursiva. Esse resto, nomeado como objeto a, revela uma impossibilidade radical na estrutura, o real. O discurso do mestre preserva o impossível de governar; o discurso da histérica, o impossível de "fazer desejar"; o discurso universitário, o impossível de educar; e o discurso do psicanalista, o impossível de analisar.

Portanto, cada discurso resguarda uma impossibilidade específica. Isso significa que não se pode, por exemplo, governar sem resto. $\mathrm{O}$ senhor, ao fazer um pequeno esforço para que a coisa funcione - ou seja, dá ordens -, perde alguma coisa. Essa coisa perdida é o resto, o real, que determina o impossível de governar. Tentar governar sem considerar o real que está em jogo é cair na própria impotência discursiva; é não assumir a impossibilidade inerente ao discurso. Isso porque não se pode governar todo o real. No entanto, é justamente esse o esforço do mestre: desconsiderar o real, a impossibilidade da estrutura.

O discurso do mestre é bastante próximo ao discurso do médico. Esse último discurso segue suas próprias leis e atribui sua coerção tanto ao médico quanto ao doente. É um discurso que impõe um comando, uma ordem, que não tem de ser defendida nem demonstrada, uma vez que ela se aplica por si mesma e deve ser executada e obedecida pelo médico. A palavra do médico não pode ser contestada, não pode ser distorcida, não é susceptível de interpelações. Seu discurso se sustenta por sua objetividade e cientificidade, excluindo assim as posições subjetivas do médico e do doente.

A posição do médico diante do doente é a de quem possui um saber sobre o que lhe afeta e, em nome da vida, é preciso obedecê-lo. Lacan (1966), ao tratar sobre o lugar da medicina na psicanálise, afirma que a ciência deposita nas mãos do médico a capacidade de produção de novos agentes terapêuticos, químicos ou biológicos. Há ainda uma exigência para que o médico coloque esses agentes à prova $\mathrm{e}$ a medicina se posiciona de forma a tentar responder a essas demandas. Dessa forma, ela ocupa e sustenta o mito do sujeito suposto saber.

No texto "Discurso médico e discurso psicanalítico", Jorge (1983), ao tratar sobre o discurso médico, afirma que o médico só existe em sua referência constante ao saber médico, ao corpo médico, à instituição médica. Ele se anula enquanto sujeito perante a exigência e o rigor da objetividade científica. "O médico só se autoriza por não ser ele próprio, por ser ele próprio o menos possível" (Jorge, 1983, p.11, grifos do autor). Ao mesmo tempo em que o médico como sujeito se apaga diante das exigências do seu saber, o doente se apaga diante da sua doença.

Observa-se que muitas vezes o médico não se dirige ao doente enquanto tal, mas ao homem normal que ele era e deverá voltar a ser. Nesse caso, o homem passa a ser definido como aquele que possui uma boa saúde e que deve seguir as prescrições médicas. A partir dessa ideia, recorremos a Jorge (1983) quando afirma que "o médico não se dirige ao doente, mas ao futuro homem são, pois se no discurso médico o doente é definido como homem + doença, o homem passa a ser definido aí como doente - doença" (Jorge, 1983, p.13).

Clavreul (1983) diz que a medicina opera reduzindo o sentido dos diferentes ditos do sujeito àquilo que é passível de ser inscrito no discurso médico. A pluralidade de sentido é abolida para dar lugar à univocidade. Nesses casos, o médico precisa se apropriar do discurso do sujeito e transformar os significantes da sua fala em signo, em sinais médicos. $\mathrm{Ou}$ seja, o trabalho do médico consistiria em descartar o que há de particular no discurso do sujeito para torná-lo legível e, desta forma, conseguir eliminar ou tratar aquilo de que o paciente se queixa. Nessa lógica não há espaço para a fala do paciente, ele não possui saber que interesse ao campo médico. Trata-se aí de um discurso que exclui a diferença, maneira pela qual a subjetividade poderia se manifestar.

A medicina tem uma função silenciadora em que a fala do sujeito é ouvida para ser descartada ou reduzida em sinais médicos. Já o psicanalista tem um posicionamento inverso: seu discurso não tem uma função silenciadora, mas uma função silenciosa, para que se promove a fala do sujeito, pois aí pode ser uma via possível para a emergência do desejo.

Enquanto a medicina impõe ao médico a necessidade de proteger-se do erro, fazendo uma seleção daquilo que escuta e retendo apenas o que é utilizável para o diagnóstico e o tratamento, Freud propõe a escuta sob atenção flutuante, aquela que não valoriza a priori nenhum elemento do discurso do sujeito, pois aí pode surgir uma verdade sobre seu desejo. Para o psicanalista, ao contrário do médico, o erro é que é seu fio condutor. Freud mostrou que os erros têm em comum o fato de não ocorrerem de qualquer modo, mas segundo leis muito referenciáveis.

O discurso psicanalítico é oponível ao discurso médico, no sentido apontado por Lacan (1969-1970/1992) quando fala do discurso do mestre como sendo a psicanálise ao avesso. Segundo ele, o analista deve se encontrar no polo oposto a toda vontade de dominar, a toda vontade de mestria. Ele diz, "a posição do psicanalista, eu articulo da seguinte forma - digo que é feita substancialmente de objeto a" 
(Lacan, 1969-1970/1992, p.44). Isso na medida em que "esse objeto a designa precisamente o que, dos efeitos do discurso, se apresenta como o mais opaco, há muitíssimo tempo desconhecido, e no entanto essencial" (Lacan, 19691970/1992, p.44).

Esse "substancialmente" que Lacan menciona parece referir-se à própria dimensão opaca, obscura do objeto a. Trata-se da impossibilidade de definir um objeto como sendo o objeto a. Apesar disso, é um objeto "essencial", o que parece revelar a dimensão do objeto a como causa de desejo. As duas ideias atribuídas a essas palavras de Lacan apontam para a função do analista enquanto objeto a. Isso significa ocupar um lugar vazio que tem como direção causar o desejo do sujeito, propiciando o surgimento do discurso do analista.

Nesse discurso, portanto, o agente é o objeto a, como causa do desejo. $\mathrm{O}$ analista na posição de objeto a não corresponde a uma pessoa ou a um ser. Ele faz função de semblante do objeto, que aparece esvaziado de substância e que não é um objeto de gozo. Fazer semblante contempla a condição que mantém sua função de causa do desejo do analisante e de um canalizador de gozo, que desvela o verdadeiro lugar do gozo para o sujeito. Dessa forma, o a como semblante é causa vazia da divisão desejante, e o analista se posiciona, quando chega o tempo do seu ato, 'semblanteando' essa causa.

$\mathrm{O}$ analista, mesmo fazendo essa função de semblante de objeto, torna-se portador de um tipo de saber que não pode ser usado em seu benefício. É um saber que vai ser construído pelo analisante a partir de cada ato que se produz no processo analítico. Aquilo que o sujeito não sabe sobre si vai ser suposto saber ao analista. O psicanalista, ao ocupar este lugar, é suposto não como aquele que sabe, mas sim como aquele que deve receber a fala do sujeito como produção de saber.

O que faz o analisante falar é a transferência como amor endereçado ao saber, que se apresenta na figura do analista como sujeito suposto saber. $\mathrm{O}$ amor de transferência desenvolve-se no campo do narcisismo e tende à identificação com o analista e à sua idealização. No entanto, é para o campo do desejo que o analista deve conduzir a análise, interrogando o sujeito na sua divisão, precisamente nos pontos onde a clivagem entre consciente e inconsciente aparece: lapsos, atos falhos, sonhos, etc.

Nesse processo, o desejo do analista tem uma função essencial, pois é a partir dele que o analista ocupa a função de pura condição desejante, conduzindo a análise na direção contrária à identificação e à idealização. O desejo do analista é fruto da ignorância, qualificada por Lacan como "douta". A douta ignorância significa que o psicanalista em sua análise pessoal passou pela experiência do inconsciente, construindo a elaboração de um saber em torno de um ponto de falta, que é o não saber. O reconhecimento do não saber é uma condição para elaboração do saber inconsciente do analisando.
No discurso do analista, o lugar do outro é ocupado por $\$$, única posição possível de escrever a estrutura do fantasma fundamental $(\mathrm{a} \rightarrow \$$ ). É nesse lugar que o sujeito interroga seu desejo e de onde vai elaborar um saber inconsciente. Lacan (1969-1970/1992) menciona que:

Para o analisante que está ali, no \$, o conteúdo é seu saber. A gente está ali para conseguir que ele saiba tudo o que não sabe, sabendo-o, contudo. $\mathrm{O}$ inconsciente é isso. Para o psicanalista, o conteúdo latente está do outro lado, em S1. Para ele, o conteúdo latente é a interpretação que vai fazer, na medida em que esta não é aquele saber que descobrimos no sujeito, mas o que se lhe acrescenta para dar-lhe um sentido. (Lacan (1969-1970/1992, p.119)

O analista, ao interrogar o sujeito em sua divisão, leva o paciente a associar, e o produto dessa associação são novos significantes que serão articulados com o saber inconsciente do próprio analisante. Dessa forma, no lugar da produção abaixo e à direita - aparece o significante mestre. No discurso do analista, o S1 tem uma função distinta daquela que apresenta no discurso do mestre. Nesse último discurso, o S1 é o agente, aquele que comanda, enquanto que no discurso do analista, ele é algo que o sujeito produziu. Por isso Lacan afirma que é pelo discurso do analista que existe alguma possibilidade de obter outro estilo de significante mestre e, ainda, que pode ser destilado um significante menos tolo.

No lugar da verdade, abaixo e à esquerda, encontra-se S2, o saber. Numa análise, toda articulação do S2 funciona no registro da verdade. $\mathrm{O}$ saber, quando se inscreve nessa posição, não trabalha, não serve como produto nem é um meio de gozo, como no discurso do mestre. No discurso do analista, esse saber constitui-se a partir de elaborações do sujeito que se desenrolam através de sua própria fala. É um saber muito particular que diz respeito à singularidade do desejo inconsciente de um sujeito. Trata-se do saber do inconsciente: "o saber é coisa que se diz, que é dita. Pois bem, o saber fala por conta própria - eis o inconsciente" (Lacan, 1969-1970/1992, p.73).

Lacan (1969-1970/1992), ao lançar a pergunta sobre o que seria a verdade como saber, responde: "É um enigma. Esta é a resposta - é um enigma" (Lacan, 1969-1970/1992, p.36). O enigma é uma enunciação e sua função é um semidizer, ou seja, um saber sobre a verdade só pode ser dito pela metade. Isso significa que não há um saber, completo e exclusivo, capaz de revelar toda a verdade do sujeito. Numa análise, a possibilidade de criar um saber sobre a verdade ocorre sempre de forma parcial, nunca completa. Conforme Lacan (1969-1970/1992) menciona: "Isso quer dizer que, se nesse campo dizemos algo de uma certa maneira, haverá uma outra parte desse mesmo dizer que vai se tornar absolutamente irredutível, totalmente obscura" (Lacan, 1969-1970/1992, 
p.115).

A verdade só é acessível por um semidizer e é inseparável dos efeitos de linguagem, o que, de fato, inclui o inconsciente. A verdade só pode ser localizada no campo onde se enuncia; uma enunciação pela metade, marcada pelos efeitos do inconsciente. Para além dessa metade, não há nada a dizer; é da ordem do indizível. Ou seja, há um ponto da verdade que escapa a toda tentativa de totalização de saber; há sempre um real irredutível que resiste à simbolização. É neste ponto de falha, onde o saber constituído se mostra como fracasso, que emerge a verdade de um sujeito particular. Daí Lacan mencionar que o efeito de verdade é apenas uma queda de saber, e é essa queda que faz produção.

$\mathrm{Na}$ experiência de análise, essa produção implica na criação de um saber particular que vem revelar a verdade do sujeito, que é a verdade do desejo. Trata-se de uma verdade e de um saber marcados pelo inconsciente e que aparecem sempre de forma parcial. Essa incompletude, que faz referência a um não saber, tem um valor de causa do movimento do inconsciente, movimento do desejo, que leva o sujeito a elaborar um saber singular sobre sua verdade.

\section{Ética da Medicina X Ética da Psicanálise}

Para que uma psicanálise seja eficaz, o analista deve sustentar sua ética onde quer que ele esteja inserido. Nesse sentido, a proposta de articular o lugar do psicanalista no hospital com a ética da psicanálise é fundamental, pois o analista está imerso num local onde rege outro tipo de ética - a da medicina - e que, por isso, o impede, muitas vezes, de compartilhar dos objetivos da equipe multidisciplinar (médicos, enfermeiros, técnicos de enfermagem, fisioterapeutas). Neste artigo, aproximaremos a ética da medicina com a ética do Bem.

Freud, em alguns momentos da sua obra, apresenta sua discordância com os preceitos da ética do Bem. A teoria freudiana estremeceu algumas convicções acerca das relações do homem com o Bem, que até então prevalecia na época. O bem é negado por Freud e, assim, a partir da noção de inconsciente, permite enfatizar a função do desejo no direcionamento da ação humana, que está no centro do tema da ética.

Ao longo de sua obra, Freud apresenta algumas concepções referentes à ética da psicanálise. Em última análise, trata-se de uma ética que remete à singularidade do sujeito e ao compromisso dele com seu desejo. Apesar das contribuições freudianas, foi Lacan quem mergulhou nos estudos sobre o tema e definiu a ética como proposta da clínica psicanalítica.

Lacan (1959-1960/2008) enfatiza a distinção entre ética do desejo e ética do Bem. Essa última ética tende a referir-se a uma ordem - ponto que, até certo nível, tem em comum com outras éticas - que não deve ser contestada e a que o sujeito deve se adaptar. Para se alcançar os costumes de uma cultura, é preciso reunir uma ordem que seria o Bem Supremo; ponto de convergência em que a ordem particular se unifica num conhecimento mais universal.

Seguindo as perspectivas do universal, do Bem Supremo, a ética do Bem comporta ainda uma idealização. Há um ideal humano, atrelado à figura do mestre, a ser seguido e buscado pelos homens. Sob essas condições, surge a crença de que se o homem seguir a ordem do ditador ou se fizer o bem, ele pode alcançar o ideal, o Bem Supremo. Trata-se de regras que são impostas ao homem e que, ao obedecê-las, ele poderá atingir a satisfação. $\mathrm{O}$ que se evidencia aí é ilusão da potência de satisfação, a prevalência da ordem do poder.

Neste ponto, pode-se retomar o contexto hospitalar. O discurso médico dita uma ordem que padroniza o sofrimento e cria um manual de normalidades para o indivíduo, no qual prega o equilíbrio e a moderação em todos os aspectos da vida, para que esta se alongue ao máximo. A medicina pressupõe imperativos universais e rigorosos e, a partir da sua ética, acredita saber o que é melhor para o sujeito, independentemente do seu desejo. Dessa forma, a medicina é exercida por meio de um apelo às normas e exige do sujeito em tratamento que ele se aliene de suas escolhas. É uma situação na qual o sujeito deve sacrificar seu desejo em benefício de sua recuperação.

Lacan (1959-1960/2008) diz que a ordem dos poderes não deve ser desprezada. No entanto, é importante conhecer o limite disso no que se refere ao campo aberto pela psicanálise. Ele afirma que a ética não é o simples fato de haver obrigações, um laço que encadeia, ordena e constitui a lei da sociedade. Logo no início do Seminário VII, afirma que pretende falar de ética e não de moral - compreendida em termo de valores, ideias de condutas, conjunto de normas e regras que funcionam como um sistema de coação social. Mas, então, o que seria a ética da psicanálise? Para desenvolver essa ideia a partir do ensino de Lacan e progredir na discussão, em alguns momentos é importante recorrer à obra freudiana.

Freud (1930/1996a), no texto "O mal-estar na civilização", lança a pergunta sobre o propósito e a intenção dos homens na vida: "o que pedem eles da vida e o que desejam nela realizar? A resposta mal pode provocar dúvidas. Esforçam-se para obter felicidade; querem ser felizes e assim permanecer" (Freud, 1930/1996a, p.84). Para isso, a intenção dos homens consiste na experiência de intensos sentimentos de prazer e também visa à ausência de sofrimento e de desprazer. A partir daí, o autor faz uma análise sobre as maneiras pelas quais o homem busca a felicidade ou os meios que utiliza para atenuar seu 
sofrimento.

Lacan (1959-1960/2008), ao retomar o texto freudiano “O mal-estar na civilização", ressalta que não escapa a Freud que a felicidade é o que deve ser proposto a toda busca. No entanto, para essa felicidade, não há absolutamente nada preparado. Ou seja, do ponto de vista da psicanálise, não existe a figura de um Bem Supremo que dita as normas ou faz promessa de uma felicidade plena.

Para Freud (1930/1996a), existem muitos caminhos que podem levar o homem a atingir a felicidade, porém nenhum é capaz de apreender tudo o que desejamos e nenhum que o faça com toda segurança. "Não existe uma regra de ouro que se aplique a todos: todo homem tem de descobrir por si mesmo de que modo específico ele pode ser salvo. Todos os tipos de diferentes fatores operarão a fim de dirigir sua escolha" (Freud, 1930/1996a, p.91).

Freud observa a importância da singularidade e do desejo do sujeito para sua salvação. Além disso, ele recusa a concepção da ética como ordem universal, onde existe alguém que possui um poder e que impõe igualmente a todos o seu próprio caminho para a aquisição da felicidade e da proteção contra o sofrimento. Freud (1930/1996a) afirma que a humanidade efetuou um grande progresso das ciências naturais e um extraordinário controle sobre a natureza. Apesar de os homens se orgulharem de suas realizações, o poder adquirido sobre o espaço e o tempo não aumentou a quantidade de satisfação prazerosa que poderiam esperar da vida nem os tornaram mais felizes.

Freud (1930/1996a) faz uma crítica à concepção do homem como um ser gentil e bondoso, pois em seus dotes pulsionais há uma poderosa cota de agressividade. Diz ainda que "a inclinação para a agressão constitui, no homem, uma disposição instintiva original e autossubsistente, e retorno à minha opinião de que ela é o maior impedimento à civilização" (Freud, 1930/1996a, p.125). A civilização constitui um processo a serviço de Eros, a pulsão de vida, cujo objetivo é criar uma unidade, a humanidade, a partir de seres humanos individuais e isolados. Mas, para alcançar esse objetivo, é preciso fazer com que os homens renunciem a uma parte das suas satisfações pulsionais e de sua agressividade.

A agressividade do homem se opõe ao programa da civilização e ameaça a sociedade civilizada com a desintegração. Dessa forma, a civilização utiliza grandes esforços para estabelecer limites para as pulsões agressivas dos homens, acreditando que assim eles serão mais felizes. Um exemplo desse esforço é a manutenção do mandamento "Amarás a teu próximo como a ti mesmo", que constitui a defesa contra tal agressividade.

Freud (1930/1996a) diz que é impossível cumprir esse mandamento e é contra a natureza original do homem, justamente pela cota de agressividade a ele inerente. Os fenômenos de agressividade e destruição decorrem da pulsão de morte. É importante ressaltar que a introdução do conceito de pulsão de morte, em 1920, na teoria psicanalítica revela uma modificação radical na teoria da pulsão. Do conceito de pulsão de morte a psicanálise pode inferir a possibilidade de pensar num caos pulsional oposto à ordem do aparato psíquico. Isso tem como consequência a queda da hegemonia do princípio do prazer - que busca alcançar o prazer e evitar o desprazer, sem entraves nem limites - no que se refere ao funcionamento do aparelho psíquico. Freud (1920/1996b) observa, a partir da clínica, uma tendência do indivíduo à repetição das experiências penosas e desprazerosas. Essa disposição é irredutível às exigências do prazer.

A pulsão de morte é o que está para "além do princípio do prazer”, além do próprio aparelho psíquico. Uma das maneiras de presentificação desse "além" no psiquismo é o caráter destrutivo, que está além da ordem, é pura potência dispersa. Esse aspecto faz jus à afirmação de Freud de que a pulsão de morte é a pulsão por excelência.

A partir da observação da compulsão à repetição é que Freud teoriza o conceito de pulsão de morte. De origem inconsciente, a compulsão à repetição leva o sujeito a se colocar repetitivamente em situações dolorosas, réplicas de experiências antigas. Mesmo que não se possa eliminar qualquer vestígio de satisfação libidinal desse processo, o princípio do prazer não pode explicá-lo. Observa-se que há um mais além do princípio do prazer.

Assim, Freud reconhece o caráter demoníaco da compulsão à repetição, comparando-o à tendência à agressão e à destrutividade. No percurso de suas observações, ele acaba formulando a hipótese de que existe uma pulsão cuja finalidade é reconduzir o que está vivo ao estado inorgânico. A pulsão de morte tornou-se, assim, o protótipo da pulsão, na medida em que a especificidade do pulsional reside nesse movimento regressivo de retorno a um estado anterior.

A pulsão de morte não pode ser localizada de forma isolada, ela está em constante confronto com Eros - que são as pulsões de vida: reunião das pulsões sexuais e das pulsões outrora designadas como pulsões do eu. A partir dessa ideia, pode-se retomar o mandamento "Amarás a teu próximo como a ti mesmo" para relembrar, como diz Freud, que em vista desse confronto, dessa agressividade, o próximo não é apenas um “ajudante potencial ou um objeto sexual, mas também alguém que os tenta a satisfazer sobre ele sua agressividade, a explorar sua capacidade de trabalho sem compensação, utilizá-lo sexualmente sem o seu consentimento, apoderar-se de suas posses, humilhálo, causar-lhe sofrimento, torturá-lo e matá-lo" (Freud, 1930/1996a, p.116). 
Se a civilização impõe sacrifícios e renúncias tão grandes ao homem, é possível compreender o motivo pelo qual é tão difícil ser feliz. Freud (1930/1996a) afirma que a civilização é em grande parte responsável pela "nossa desgraça" (1930/1996a, p.93) e acrescenta que a defesa contra a agressividade pode causar tanta infelicidade quanto ela própria. Entretanto, segundo Freud (1908/1996c), a civilização apenas consegue atingir nos homens "uma supressão aparente de seus instintos, supressão essa que se torna cada vez mais falha" (Freud, 1908/1996c, p.177).

$\mathrm{O}$ autor critica o programa da civilização por atender de forma inadequada às exigências de uma vida que torne os homens mais felizes e por permitir a existência de tanto sofrimento que talvez pudesse ser evitado. Ao tentar mostrar as falhas da civilização, Freud espera que se possam efetuar alterações na civilização que satisfaçam melhor as necessidades dos homens, levando em consideração sua própria constituição.

Seguindo essas perspectivas, observa-se que à medida que Freud descaracteriza o ser humano como bom e aponta a impossibilidade de uma conduta ética como modelo coletivo, ele está rompendo com a ética do Bem. Nesse sentido, a ética da psicanálise não é uma ética que visa ao Bem Supremo e à universalização moral. Ela é, antes de tudo, uma ética que visa a fazer emergir o desejo de cada sujeito na sua particularidade.

O psicanalista, referenciado pela ética do desejo, não está autorizado a ordenar o que é melhor para o sujeito, a partir da posição do sujeito que sabe. A psicanálise não pretende ajustar o paciente a um padrão de normalidade que exclui as particularidades do sujeito. Freud afirma que a regra fundamental da psicanálise é a associação livre, ponto que marca o início do tratamento analítico. Segundo as ideias freudianas, essa regra não está do lado do analista, mas sim do paciente. Do lado do analista, fora o preceito da atenção flutuante, não há regras, mas há a ética da psicanálise que é a ética do desejo.

Lacan (1959-1960/2008) desenvolve sua proposta de uma ética da psicanálise como ética do desejo referenciada ao real. Afirma que essa dimensão não incide no domínio do ideal. Isso porque a ética da psicanálise opõe-se a qualquer forma de universalização moral, do poder e imposições de um mestre. Sua crítica diz respeito à ética do Bem, cuja relação do homem com sua ação é regida por ideais que pressupõem o alcance de um bem, que engendra um ideal de conduta e promete uma relação harmônica entre os homens.

Observa-se que Lacan não despreza a relação do sujeito com o outro - o que ele faz é uma crítica no que tange às relações do Bem, ideal e harmônica, que desconsideram e descartam a existência da falha que aponta para o impossível da relação harmoniosa, a hiância da estrutura, o real em jogo. De acordo com as concepções lacanianas, é a partir dessa falha que o desejo pode emergir.

Freud, ao tratar da primeira experiência de satisfação, já apontava para uma impossibilidade na relação do sujeito com o outro. Esse primeiro encontro inscreve o sujeito no campo do desejo. É importante abrir um parêntesis para esclarecer que, neste momento do artigo, retomar a experiência de satisfação auxiliará a avançar na discussão sobre a ética pautada no real e no desejo, tal como Lacan a designa. Conforme se verá adiante, a experiência de satisfação de Freud é uma noção fundamental para abordar o conceito lacaniano de das Ding, desenvolvido no Seminário VII, A ética da psicanálise.

Portanto, vamos retomar Freud (1895/1996e) com a experiência de satisfação que se liga à concepção de desamparo original do indivíduo. Esse desamparo, que pode ser o grito - descarga da tensão -, coloca o recém-nascido numa total dependência da pessoa responsável pelos seus cuidados, uma vez que ele não consegue realizar a ação específica que suprimiria sua tensão. Dessa forma, essa ação só pode ser realizada por outra pessoa que lhe fornece o alimento, por exemplo. Essa pessoa transforma o grito, o apelo, em demanda, propiciando o acesso do sujeito ao campo do Outro. É a eliminação da tensão interna causada por um estado de necessidade que dá lugar à experiência de satisfação.

Essa experiência fica associada à imagem do objeto que proporcionou a satisfação, bem como à imagem do movimento que permitiu a descarga. Em decorrência da associação estabelecida, na próxima vezque uma necessidade desta natureza for despertada, surgirá imediatamente um impulso psíquico que procurará reinvestir a imagem mnêmica do objeto, restabelecendo a situação de satisfação original. Um impulso dessa espécie "é o que chamamos de desejo; o reaparecimento da percepção é a realização de desejo, e o caminho mais curto para essa realização é a via que conduz diretamente da excitação produzida pelo desejo para uma completa catexia da percepção" (Freud, 1900/1996d, p.594).

No entanto, o que é reativado é o traço mnêmico da imagem do objeto sem que essa reativação seja acompanhada da imagem real do objeto. Portanto, o que se produz é uma alucinação. O bebê apresenta o ato reflexo cujo objetivo é a posse do objeto, mas como ele não é capaz de distinguir o objeto real do objeto alucinado, surge a frustração. Ressaltase que Lacan (1956-1957/1995) aponta a frustração como uma das três formas da falta de objeto, que é a própria mola da relação do sujeito com o mundo.

Assim, a experiência de satisfação é a marca da impossibilidade do sujeito com o objeto, e esse primeiro encontro inscreve o sujeito no campo do desejo. Essa 
experiência ligada à imagem do objeto deixa sua marca no aparelho psíquico e introduz o sujeito no circuito pulsional, passando da demanda ao desejo. A partir daí, o indivíduo se lança numa busca infindável desse objeto causa de desejo, dessa Coisa perdida - das Ding - que, embora nunca tido, tentará ser reencontrado.

Lacan aborda o conceito de das Ding a partir das considerações de Freud sobre a Coisa. Tomando como referência o Projeto para uma psicologia científica (1895/1996e), Lacan recorre à questão de como a realidade se constitui para o homem. A primeira apreensão da realidade pelo sujeito se dá através do próximo, com quem ele aprende a reconhecer. Este reconhecimento está marcado por uma divisão: de um lado os traços de memória reconhecíveis no campo perceptivo que, nas palavras de Freud, podem ser compreendidos. Do outro lado, algo permanece não assimilável, intraduzível, que resiste ao reconhecimento - das Ding -, com o qual o sujeito se depara na experiência com o próximo. Essa divisão original da experiência da realidade aponta que no reconhecimento do próximo há algo que resiste e escapa como uma Coisa, que aparece de forma enigmática, estranha ou hostil. Isso significa que esse reconhecimento jamais será total.

Essa Coisa é designada por Lacan como das Ding: "Trata-se desse interior excluído que, para retomarmos os próprios termos do Entwurf [Projeto], é, deste modo, excluído no interior. No interior de quê?" (Lacan, 19591960/2008, p.128). Lacan se questiona sobre esse interior - ressalta-se que não se trata do interior do aparelho psíquico, pois, nesse momento, ele ainda está se formando - e responde que é de algo que se articula com o Real-Ich, "o real derradeiro da organização psíquica" (Lacan, 19591960/2008, p.128). Em síntese, o Real-Ich é um estado originário do psiquismo no qual ainda não há diferenciação entre o eu e o mundo exterior, nem oposição prazerdesprazer. Nesse momento, ainda não há organização psíquica, que ocorrerá posteriormente.

Das Ding é o que é excluído desse real psíquico, e não parte integrante dele. O que temos nesse lugar é um buraco, um vazio, que é o índice de que, na realidade, das Ding deve ser estabelecido como exterior. A partir desse vazio, o sujeito busca reencontrar das Ding, que é, entretanto, um objeto perdido, nunca tido, impossível de alcançar, em relação ao qual o sujeito mantém uma "distância íntima que se chama proximidade" (Lacan, 1959-1960/2008, p.97). Daí, portanto, nota-se uma primeira noção, ainda que de forma sucinta, do desejo apontando para o real, o impossível, já que das Ding, objeto causa de desejo, será sempre inatingível.

Lacan (1959-1960/2008) afirma que das Ding é o elemento que é originalmente isolado pelo sujeito em sua experiência do Nebenmensch - o semelhante, o primeiro a cuidar do recém-nascido em seu desamparo. É um elemento que, daquilo que é do interior do sujeito, é levado para um primeiro exterior. Ele se apresenta e se isola. Lacan destaca que é em torno desse objeto - que ocupa para o sujeito o lugar de primeiro exterior, o Outro pré-histórico impossível de esquecer, de uma impressão à qual nada no campo das percepções pode corresponder - que se orienta todo o encaminhamento desejante do sujeito.

É esse objeto, das Ding, enquanto Outro absoluto do sujeito que se trata de reencontrar. No entanto, esse objeto é, por sua natureza, perdido como tal e jamais será reencontrado. Lacan destaca que esse objeto, na verdade, nunca foi perdido, apesar de tratar-se essencialmente de reencontrá-lo. Nesses sucessivos reencontros surge o caráter real do objeto faltoso; a Coisa comparece sempre a cada vez que o sujeito reencontra o objeto. O movimento de busca do sujeito implica que encontrar esse objeto seja sempre reencontrá-lo, sem, de fato, encontrá-lo.

A partir das ideias aqui expostas, observa-se que, para a psicanálise, não existe o Bem Supremo, que é das Ding, mantido pela ética do Bem. Isso porque não há um objeto que corresponda a esse Bem, capaz de fornecer a plena satisfação pulsional. No lugar do Bem Supremo, há um vazio, marcado pelos rastros de das Ding. Esse vazio possibilita as constantes buscas do sujeito pelo objeto causa de seu desejo, sempre inatingível. Resta ao sujeito a tarefa de contornar o vazio com sua palavra, com alguma criação que o represente.

Lacan (1959-1960/2008) menciona a noção de criação no Seminário VII. Afirma que toda criação se faz ex nihilo, ou seja, a partir do nada. A partir da construção de um vaso, por um oleiro, menciona que a criação é a moldura que busca contornar o vazio que permanece no centro. Essa Coisa, em torno da qual se fazem todas as formas criadas pelo homem, será sempre representada por um vazio, precisamente pelo fato de ela não poder ser representada por outra coisa. $\mathrm{Ou}$ seja, é a partir de das Ding, do ex nihilo, do nada, que advém a criação, o contorno do vazio.

Ao tratar extensamente da questão da sublimação no Seminário VII, Lacan (1959-1960/2008) propõe que um objeto criado implica na novidade do objeto, sua originalidade. A criação, ao se constituir a partir do ex nihilo, introduz uma novidade no que existia antes. O objeto criado é incapaz de recobrir o vazio; o vazio é parte integrante da criação que ousa contorná-lo. A ética pautada no real aponta justamente para essa dimensão criativa, que pressupõe o enfrentamento desse vazio para em seguida bordejá-lo com palavras ou com um objeto inventado. A psicanálise conduz o sujeito a se deparar com o vazio, a falta-a-ser com a produção de um estilo próprio do sujeito, um modo de vida que contemple a dimensão do desejo. 
Lacan (1959-1960/2008) esclarece que desde a origem do pensamento moralista, desde Platão e Aristóteles, toda a concepção acerca do bem do homem fez-se em função do índice de prazer. Há uma tentativa de apontar os verdadeiros e falsos bens que o prazer indica. No entanto, nada é mais tentador do que eludir a questão do bem com um bem harmonioso a ser reencontrado no caminho do desejo. Lacan nos alerta contra as vias enganadoras do bem e afirma a imprudência de posturas que ditam promessas de todos os bens como acessíveis. Nesse sentido, a dimensão do bem levanta uma muralha poderosa na via do desejo.

Ao contrário dessa concepção, a experiência analítica é um convite para o acesso a essa via do desejo, possibilitando uma mudança na relação do sujeito com o bem. Esse desejo não se submete a normalização nem a leis universais, constituindo-se em uma singularidade do sujeito. A ética da psicanálise parte da universalidade do desejo para enfatizar a sua particularidade, e não como uma forma de universalização moral fundada em algum ideal. Para a ética da psicanálise, o universal é a diferença.

No final do seu Seminário, Lacan (1959-1960/2008) acrescenta que não se trata de negar o campo dos bens e indica uma proposta diferente daquela abordada pela ética do Bem: "Não há outro bem senão o que pode servir para pagar o preço ao acesso ao desejo" (p.385). Mais adiante, ele diz: "Sublimem tudo o que quiserem, é preciso pagar com alguma coisa. Essa alguma coisa se chama gozo. (...) Eis o objeto, o bem, que se paga pela satisfação do desejo" (Lacan, 1959-1960/2008, p.386). A ideia lacaniana é que o acesso ao desejo implica numa perda de gozo, em abrir mão da ilusão da satisfação plena, em ultrapassar toda piedade diante do bem do outro. $\mathrm{O}$ acesso ao desejo não é uma via que se possa avançar sem nada pagar: paga-se um preço!

Diante desse contexto, talvez também se possa atribuir esse preço à passagem pela experiência trágica da vida, tal como Lacan (1959-1960/2008) a formula. Essa experiência marca uma causa perdida, a falta do objeto, a castração, o enfrentamento inevitável com a morte, uma vez que, de fato, não há nenhum Bem no horizonte do sujeito que poderia satisfazer o seu desejo. O que se evidencia aí é que a ética do desejo aponta para o real impossível, para aquilo que "não para de não se escrever" (Lacan, 19721973/1985, p.127), no regime do encontro sempre faltoso. Trata-se de uma ética que remete ao próprio movimento do inconsciente que se instaura numa prática da diferença que remete ao desejo.

Lacan chama a atenção para as dificuldades de sustentação da ética da psicanálise referenciada ao real fora do contexto da psicanálise em intensão. Aqui podemos retomar algumas dificuldades e impasses apresentados ao psicanalista quando ele se insere nos hospitais, espaço onde impera a ética da medicina. Assim, surgem as perguntas: De que maneira o psicanalista poderia sustentar sua ética nos hospitais? Há uma interlocução possível entre psicanálise e medicina?

As diferenças entre a psicanálise e a medicina poderiam ser um obstáculo para a articulação entre esses dois campos ou poderiam impedir a viabilização da psicanálise no hospital. Entretanto, é exatamente essa distância que permite a aproximação entre a psicanálise e a medicina, pois o real faz parte da estrutura do sujeito e vai sempre retornar e insistir. A medicina não tem recursos para tratar dessa dimensão e, por isso, solicita a presença do psicanalista.

Psicanálise e medicina, trata-se de um encontro possível que advém de um encontro impossível no que tange às diferenças dos seus discursos e de suas éticas. Os efeitos dessa aproximação exigem do analista um esforço para não perder de vista a dimensão específica da psicanálise. Essas questões certamente se tornam desafiadoras para a legitimidade da psicanálise nos hospitais.

\section{E Então, Qual o Lugar do Psicanalista no Hospital?}

A partir das ideias discutidas ao longo deste artigo, apresentamos alguns desafios que o psicanalista enfrenta quando se insere em hospitais gerais. Esses desafios certamente nos convocam ao questionamento sobre a legitimidade da psicanálise nesses locais. Isso porque, diante desses desafios, muitas vezes observa-se uma descaracterização e até mesmo uma alteração dos fundamentos da psicanálise por parte dos profissionais que se dizem psicanalistas. Quando o psicanalista se insere num local marcado pelos critérios de eficácia e por um discurso que visa à restauração da saúde perdida, ele pode levar a psicanálise a se diluir nesses tratamentos que propõem o bem-estar. Nesse sentido, delimitar o lugar do psicanalista a partir da dimensão clínica - vertente do discurso e da ética foi fundamental, já que essas vias são subsídios teóricos que sustentam a prática onde quer que o psicanalista atue. No contexto hospitalar, o analista é constantemente convocado a sustentar o lugar da sua prática.

Ao investigar o lugar do psicanalista no hospital, a partir da vertente do discurso e da ética, observa-se que a função do analista nos hospitais é a mesma do consultório particular. No entanto, no contexto hospitalar, ele é obrigado a lidar com muitas variáveis que não se apresentam no seu trabalho no consultório. O psicanalista no hospital se afasta das normas e padrões adotados pelas técnicas convencionais. Ele constantemente se depara com situações imprevisíveis, mas que, ao mesmo tempo, convocam seu trabalho. Além disso, o analista no hospital faz parte da equipe e não tem como se desprender dela. Em relação aos atendimentos, na maioria das vezes é o analista que vai até o paciente sem ainda ter uma demanda de análise. Nota-se, portanto, que 
são várias as situações específicas do hospital com que o analista se depara.

Diante desta discussão, percebe-se que o lugar do psicanalista no hospital pode ser abordado a partir de duas dimensões que não se excluem e, ao mesmo tempo, se articulam: a dimensão da clínica psicanalítica e a dimensão da instituição. Ao se tratar o lugar do psicanalista a partir do discurso e da ética, delimitou-se esse lugar a partir da dimensão da clínica. Isso significa que do ponto de vista dessa dimensão, a função do psicanalista no hospital não se distingue daquela que o analista ocupa nos consultórios ou em qualquer lugar onde ele atue.

No entanto, quando esse lugar é investigado a partir da dimensão institucional, ele se torna específico do hospital, ou seja, diferente daquele do enquadre convencional. Isso porque, no contexto hospitalar, o analista precisa lidar com situações particulares desses locais. É importante enfatizar que essas situações devem ser enfrentadas e discutidas a partir dos princípios da psicanálise, isto é, da dimensão clínica. Portanto, trata-se de duas dimensões que estão articuladas.

Até este momento do artigo, investigamos, principalmente, o lugar do psicanalista a partir da dimensão da clínica. Agora, faz-se necessária a discussão sobre o lugar do psicanalista a partir da dimensão institucional. Isso significa pesquisar sobre as diversas situações - aquelas que não se apresentam no consultório - com que o analista é obrigado a lidar quando trabalha num hospital geral.

\section{O Lugar do Psicanalista nos Hospitais Gerais: Dimensão Institucional}

\section{A Criatividade do Analista nos Hospitais Gerais}

$\mathrm{Na}$ instituição hospitalar, o analista lida com muitas variáveis que não se apresentam no consultório. Em função dessas variedades, o psicanalista no hospital constantemente se depara com situações imprevisíveis, mas que, ao mesmo tempo, convocam seu trabalho. Para que esse trabalho seja possível, é preciso contar com sua criatividade, ou seja, é imprescindível o saber fazer do analista no que concerne às condições para que a prática do trabalho analítico seja possível.

Neste ponto, introduziremos a hipótese de que essa criatividade é uma condição necessária para que o trabalho do psicanalista no hospital seja viável. A partir da prática, é possível mencionar situações que nos levam a considerar a hipótese proposta. A reflexão desses acontecimentos articulados à criatividade tem como referência a ideia lacaniana de que toda criação se faz a partir de um vazio, uma vez que ela busca contornar esse ex nihilo. A criação introduz algo novo no que existia antes. No entanto, essa novidade ou o objeto criado é incapaz de recobrir todo o vazio, pois este é parte integrante da criação que vai contorná-lo. Conforme veremos adiante, o analista no hospital, por meio do ato criativo, vai justamente contornar esse nada, uma vez que isso se torna condição mínima para prática do seu trabalho.

Nos hospitais, podemos relacionar esse vazio às situações imprevisíveis, de urgência e de crise. Diante dessas circunstâncias, a criatividade é essencial para que o trabalho se dê. Por exemplo, pode acontecer de o analista estar atendendo um paciente e um médico chegar para examiná-lo. Dependendo da gravidade do caso, às vezes, é preciso que o analista interrompa o atendimento justamente num momento importante do processo analítico. Pode acontecer também que o analista esteja atendendo um familiar no momento em que o paciente falece, ali, na sua frente. Ou ainda, que o psicanalista seja abordado, nas escadarias do hospital, pela equipe da enfermagem para atender um familiar que está "aos berros" no corredor, pois o paciente acabou de sofrer uma parada cardíaca e o familiar precisou sair do quarto para que ele fosse atendido. Recorremos também às diversas situações dos familiares no CTI em que muitas vezes o psicanalista precisa se aproximar - ou até criar situações para isso ocorrer - e oferecer sua escuta, pois dali pode surgir uma demanda. Mencionamos ainda aquelas situações em que o paciente é atendido em enfermarias com várias pessoas internadas no mesmo local e que começam a ouvir o atendimento dele - chegando até a oferecer conselhos e opiniões.

Todas essas circunstâncias nos levam a perceber quanto o analista se afasta dos padrões de um consultório particular. Apesar de sua criatividade também ser condição fundamental para a prática nos consultórios, o trabalho nos hospitais requer uma maior atividade do analista quanto à criação. Talvez isso se justifique exatamente pelas diversas situações imprevisíveis e pela presença maciça do real, que aí aparece de forma escancarada. São situações que apontam para o vazio e, consequentemente, para a possibilidade de criação. Dessa forma, considera-se a criatividade do analista como uma condição necessária para que o trabalho analítico se estabeleça na instituição hospitalar. É possível localizar essa capacidade do psicanalista aqui descrita como uma particularidade do trabalho analítico no hospital.

\section{O Psicanalista na Equipe Multiprofissional}

O psicanalista no hospital não atua sozinho, como no consultório particular. Ele faz parte de uma equipe multiprofissional da qual não pode se desvencilhar. Ele é visto pelo paciente como um membro da equipe, por isso, o que ocorre na clínica com o analista tem consequência na relação do paciente com a equipe, e desta com o analista. 
Por ter como referência um discurso e uma ética diferentes dos outros profissionais da equipe, é muito importante que o psicanalista tenha clareza da sua função, para que sua condução não se misture com as outras práticas.

O lugar do psicanalista na equipe de saúde não depende da estruturação de vagas disponíveis para o cargo de "psicólogo" nem de um contrato. É um lugar que não existe a priori e se dá ao longo da construção de uma relação transferencial com a equipe. Para a construção desse lugar é fundamental que o analista ofereça seu trabalho. Isso porque são mínimas as chances de a equipe fazer demanda à psicanálise se esta não lhe for ofertada, ou seja, é preciso que o psicanalista inserido numa instituição hospitalar faça oferta da psicanálise para criar uma demanda específica.

A construção do lugar do psicanalista na equipe depende, entre outras coisas, do tipo de demanda que a equipe lhe dirige e da maneira como o analista responde a ela. O desafio é acolher essas solicitações, mas saber recuar quando for necessário, pois nem toda demanda requer a intervenção do analista - como, por exemplo, um pedido para acalmar, convencer ou eliminar algum fenômeno psíquico -, mas certamente indica uma dificuldade da equipe em lidar com a subjetividade do paciente.

$\mathrm{Na}$ presença de outros campos que se distinguem da clínica psicanalítica, o posicionamento do analista é o de transmitir a psicanálise - o termo transmissão é aqui designado não como um ensino ou um saber único e total a ser atingido. A transmissão da psicanálise se articula ao próprio discurso do psicanalista, onde se produz o impacto da destituição de um saber completo, possibilitando a produção do singular e o aparecimento do desejo observando o particular de cada caso. A partir do momento em que o psicanalista entra no hospital, há uma espécie de extensão da escuta psicanalítica e, nesse sentido, cabe ao analista tornar a psicanálise presente no mundo.

De fato, essa transmissão é um desafio para o analista no hospital. Isso porque ele vai transmitir, entre outras coisas, a noção de singularidade do sujeito para profissionais que tendem a padronizar o sofrimento e praticamente se recusam a pensar nas particularidades. Muitas vezes, as concepções psicanalíticas podem ser úteis ao médico que passa a perceber, por exemplo, as diferenças entre as ações de um paciente, do ponto de vista comportamental, e sua posição subjetiva frente à doença, que o implicará no seu tratamento. Obedecer às regras diante de uma doença não é a mesma coisa que estar implicado em seu tratamento.

Apesar das tentativas da equipe de enquadrar o sujeito a um determinado padrão de doença, existem maneiras singulares de o sujeito se relacionar com sua patologia. A maneira inédita pela qual cada paciente apresenta sua doença é recebida pela equipe como uma interferência no ritmo normal do tratamento. Esses escapes do sujeito frente àquilo que era esperado deixam a equipe transtornada em relação à condução do tratamento. É nesses momentos que a presença do psicanalista também pode ser solicitada pela equipe.

Essa situação surge como um desafio para a equipe, já que o saber acumulado por cada profissional não é capaz de dar conta da relação particular do paciente com sua doença - aquela que escapa a qualquer tipo de enquadramento, de padrões de normalidade. Manter tal impasse pode proporcionar uma circulação de hipóteses formuladas pela equipe com a finalidade de construir um saber não todo acerca de como tratar um paciente que tem determinada patologia, levando em consideração o particular de cada caso. Trata-se de construir um saber possível que inclua o impossível de saber, uma vez que o sujeito pode sempre escapar ao comportamento padrão da doença.

Por outro lado, pode acontecer também de a equipe resistir às concepções psicanalíticas ou não levar em consideração a tentativa de transmissão da psicanálise. Nesse caso, observa-se que os médicos permanecem presos aos subsídios teóricos do seu discurso e da sua ética. Dessa forma, não há articulação possível com a psicanálise, que se fundamenta em outra metodologia. De fato, eles nada querem saber sobre o que tem a dizer um outro discurso diferente do seu.

Diante desse impasse, talvez caiba ao analista transmitir a psicanálise até onde exista uma demanda de saber por parte dos médicos. Esse é um ponto fundamental para a transmissão da psicanálise no hospital. Lacan nos lembra que "os limites éticos da análise coincidem com os limites de sua práxis" (Lacan, 1959-1960/2008, p.32), uma vez que essa práxis ocorre num campo de linguagem e se desenvolve a partir de um querer saber do analisando - ressalta-se que aqui estamos aproximando o médico do analisando apenas no que diz respeito aos seus posicionamentos para que o discurso analítico opere. Entretanto, são nesses momentos de impasses que muitos analistas abrem mão dos princípios psicanalíticos e se deixam levar pelo discurso e pela ética do médico. Alguns chegam a enfatizar a impossibilidade da psicanálise no hospital.

No entanto, se considerarmos a ideia lacaniana de que o analista é efeito do seu discurso, a possibilidade da psicanálise no hospital decorre da maneira pela qual o analista sustenta seu discurso e as especificidades da sua clínica. Caso contrário, a psicanálise perde sua eficácia. Além disso, afirmar que é impossível utilizar a psicanálise no hospital porque este é um espaço onde prevalecem o discurso e a ética do médico, seria colocar a psicanálise no lugar de ideal. Seria também desconsiderar as diferenças e voltar-se para um discurso universal. Portanto, usar a psicanálise no contexto hospitalar é um convite para a 
inscrição do discurso analítico na interface dos outros discursos no mundo, e verificar seus efeitos. "Não temos outro desígnio senão o de advertir os analistas sobre o deslizamento sofrido por sua técnica, quando se desconhece o verdadeiro lugar em que se produzem seus efeitos" (Lacan, 1958/1998, p.618).

Entretanto, toda essa situação é um grande desafio para o analista, que muitas vezes é um empregado do hospital, pode estar subordinado a uma hierarquia médica à qual ele deve prestar explicações sobre seus atos e afirmações. Seja como for, o analista deve operar a partir do que advém da clínica, que são tanto as palavras e as ações de cada paciente quanto os efeitos de sua intervenção. Daí ele pode extrair indicações que sustentam a direção do seu tratamento, e caso seja necessário, pode prestar contas de sua clínica.

\section{Com a Oferta, Cria-se a Demanda}

O analista, ao se oferecer fazendo semblante para escutar e intervir em algumas situações do contexto hospitalar, possibilita a criação da demanda de análise. Neste ponto, faz-se necessário recorrer à frase lacaniana: “Com a oferta, criei a demanda" (Lacan, 1958/1998, p.623), diz o autor ao mencionar que conseguiu o que no comércio comum se gostaria de poder realizar tão facilmente.

Tanto nos hospitais gerais quanto nos consultórios particulares, quem se oferece é o analista. A oferta está sempre do lado do analista e a demanda de análise do lado do paciente. No entanto, entre esses dois espaços, há diferenças na maneira pela qual o analista vai fazer essa oferta, que é oferta de presença e de escuta. Se no consultório é o paciente que vai até o analista para que assim a oferta seja feita, nos hospitais, é o analista que vai até o paciente (no leito, na enfermaria, no CTI) ou até os familiares (por exemplo, no horário de visita dos pacientes internados no CTI).

No consultório, geralmente é o próprio paciente (adulto) que procura o analista. Já nos hospitais, muitas vezes o pedido de atendimento não vem por parte do paciente, mas da equipe médica ou dos familiares. $O$ analista, após escutar e avaliar o pedido de atendimento, seja de quem for, vai até o paciente e oferece sua escuta. Às vezes o paciente de fato aceita o tratamento e constitui uma demanda de análise, às vezes não, e ainda diz: "Concordei com o tratamento psicológico porque meu médico mandou" ou "concordei porque minha mãe não parava de falar nisso e aceitei por ela". Ressalta-se que mesmo nesse último caso, após algumas idas do analista até o paciente, a demanda pode acabar surgindo. Outras vezes pode não surgir, o que impediria o início de uma análise. Nem sempre que se oferece a escuta se tem demandas, mas se a oferece é porque supõe a existência de demandas. É nisso que o analista aposta ao ir até o leito do paciente ou quando se aproxima dos familiares no CTI. Então, onde há oferta pode surgir a demanda, e se surge a demanda é porque existe a possibilidade de ela ser escutada. Assim, é pela presença e pela atuação do analista que a demanda de análise pode ser construída.

\section{Considerações Finais}

Ao longo da minha experiência nos hospitais gerais, intrigava-me com muitas questões sobre o fazer psicanalítico nessas instituições. Essas questões surgiram, principalmente, a partir dos impasses e desafios com que me deparei na prática. Neste estudo, apresentamos essas questões relativas à prática e, na tentativa de buscar respostas, ainda que sucintas, recorremos à teoria. Nesse percurso, privilegiamos a recomendação freudiana de não distorcer os princípios da psicanálise diante da extensão da psicanálise para além dos consultórios.

Fazer a articulação entre a prática e a teoria foi uma tarefa árdua, pois as principais referências desta pesquisa, Freud e Lacan, não teorizaram sobre a inserção da psicanálise nos hospitais. Esse fato faz com que a clínica psicanalítica constantemente se misture a outros campos do saber. Dessa forma, a extensão da psicanálise exige do analista responsabilidade com sua formação e com a formalização da práxis analítica. Essas exigências são fundamentais para refletirmos sobre as condições de possibilidade para sustentar o lugar do psicanalista no hospital.

O lugar do psicanalista nos hospitais gerais foi investigado a partir de duas dimensões que devem ser articuladas: a dimensão da clínica psicanalítica e a dimensão da instituição hospitalar. Em relação à dimensão da clínica, investigamos o lugar do psicanalista a partir da vertente do discurso e da ética. Essas vertentes são subsídios teóricos que sustentam a prática analítica nos hospitais e convocam o analista a ocupar um lugar particular. Ao mesmo tempo, elas apontam para diferenças radicais entre a psicanálise e a medicina.

As distinções radicais entre a psicanálise e a medicina assinalam também grandes desafios para o analista que se insere nos hospitais. Mencionamos alguns fatores que poderiam servir como verdadeiros obstáculos para a atuação do psicanalista no hospital. Em última instância, concluímos que esses impasses e desafios não impedem a viabilidade da psicanálise nesses locais e que as condições de possibilidade para se sustentar a psicanálise nos hospitais dependem fundamentalmente da formação do analista e da formalização da práxis analítica. Nesse sentido, o que legitima o trabalho analítico no hospital é o próprio psicanalista, que deve sustentar a existência do inconsciente a partir dos próprios dispositivos psicanalíticos. Para cada analista, trata-se de reinventar os meios para a instalação 
desses dispositivos, no particular de cada caso.

Ao investigarmos o lugar do psicanalista nos hospitais gerais a partir da dimensão clínica e da dimensão institucional, concluímos que a função do analista no contexto hospitalar deve ser pesquisada considerando-se essas duas dimensões. Primeiro porque é na vertente clínica que encontramos o arcabouço teórico da psicanálise, ou seja, aquilo que sustenta o trabalho do analista. Segundo porque o analista no hospital não pode estar numa exterioridade absoluta em relação à instituição hospitalar. O psicanalista, ao querer se desembaraçar de toda responsabilidade dos critérios de funcionamento institucional, pode ser isolado e até mesmo desligado da instituição.

Ao argumentarmos sobre o lugar do psicanalista nos hospitais a partir da dimensão clínica, concluímos que sua função é a mesma que a do consultório privado ou em qualquer lugar onde ele atue. Entretanto, quando esse lugar é investigado a partir da dimensão institucional, a função do analista se torna específica desse local, ou seja, diferente daquela do consultório. No título deste artigo, "O lugar do psicanalista nos hospitais gerais: entre os dispositivos clínicos e os dispositivos da instituição hospitalar", afirmamos que o lugar do psicanalista nessa instituição se encontra entre essas duas dimensões. Assim, concluímos que a função do analista nos hospitais gerais é específica desse local, mas ele deve se orientar pela dimensão clínica.

Refletir sobre a dimensão institucional nos conduziu a traçar particularidades da clínica psicanalítica nos hospitais gerais. Discutir sobre essas particularidades foi um ponto essencial para esta pesquisa, pois implica na tentativa de formalizar teoricamente alguns elementos da prática, ainda que de forma bastante tímida.

Após expor e desenvolver essas particularidades, ficamos com a impressão de que apenas introduzimos um assunto que requer maiores discussões e que ainda pode ser explorado. Além disso, refletir sobre as particularidades mencionadas neste artigo indica abertura para pensarmos em outras particularidades da clínica que não foram trabalhadas. Por exemplo, a questão da transferência no hospital. Investigar essas condições particulares fica como propostas para outros estudos.

\section{Referências}

Clavreul, J. (1983). A ordem médica: Poder e impotência do discurso médico. São Paulo: Brasiliense.

Freud, S. (1996a). Projeto para uma psicologia científica. In J. Strachey (Ed.), Edição Standard Brasileira das Obras Psicológicas Completas de Sigmund Freud (Vol. 1). Rio de Janeiro: Imago. (Originalmente publicado em 1895)
Freud, S. (1996b). A interpretação dos sonhos. In J. Strachey (Ed.), Edição Standard Brasileira das Obras Psicológicas Completas de Sigmund Freud (Vol. 5). Rio de Janeiro: Imago. (Originalmente publicado em 1900)

Freud, S. (1996c). Moral sexual civilizada e doença nervosa moderna. In J. Strachey (Ed.), Edição Standard Brasileira das Obras Psicológicas Completas de Sigmund Freud (Vol. 9). Rio de Janeiro: Imago. (Originalmente publicado em 1908)

Freud, S. (1996d). Além do princípio do prazer. In J. Strachey (Ed.), Edição Standard Brasileira das Obras Psicológicas Completas de Sigmund Freud (Vol. 17). Rio de Janeiro: Imago. (Originalmente publicado em 1920)

Freud, S. (1996e). O mal-estar na civilização. In J. Strachey (Ed.), Edição Standard Brasileira das Obras Psicológicas Completas de Sigmund Freud (Vol. 21). Rio de Janeiro: Imago. (Originalmente publicado em 1930 [1929])

Jorge, M. A. C. (1983). Discurso médico e discurso psicanalítico. In J. Clavreul (Ed.), A ordem médica: Poder e impotência do discurso médico (pp.7-25). São Paulo: Brasiliense.

Lacan, J. (1995). O seminário, livro 4: A relação de objeto (1956-57). Rio de Janeiro: Jorge Zahar.

Lacan, J. (1998). A direção do tratamento e os princípios de seu poder. In J. Lacan, Escritos (pp.591-652). Rio de Janeiro: Jorge Zahar.

Lacan. J. (2008). O seminário, livro 7: A ética da psicanálise1(1959-60). Rio de Janeiro: Jorge Zahar.

Lacan, J. (2001). O lugar da psicanálise na medicina. Opção Lacaniana. Revista Brasileira Internacional de Psicanálise, 32, 8-14.

Lacan. J. (1992). O seminário, livro 17: O avesso da psicanálise (1969-70). Rio de Janeiro: Jorge Zahar.

Lacan, J. (1985). O seminário, livro 20: Mais, ainda (197273). Rio de Janeiro: Jorge Zahar.

Souza, A. (2008). Os discursos na psicanálise. Rio de Janeiro: Companhia de Freud. 
Endereço para correspondência:

Maíla Do Val Machado

Quadra 105, Lote 02. Resid. Flores do Ipê, apto 606A.

Bairro Águas Claras. Brasília/DF. CEP: 71915-250.

E-mail: mailamachado@yahoo.com.br

Endereço para correspondência:

Daniela Sheinkman Chatelard

Endereço: SQN 206, Bloco J, apt 105. Brasília/DF.

CEP: 70844-100

E-mail: dchatelard@gmail.com 